\title{
THE MOON IN LITHUANIAN FOLK TRADITION
}

\author{
Jonas Vaiškūnas
}

\begin{abstract}
The paper is an attempt to summarize the available Lithuanian folk knowledge about the Moon. The ethnoastronomical materials that have been collected during expeditions since 1988 as well as ethnographic and folklore archive data in written sources are used in this work. Lithuanian ethnographical material gives far more information about the Moon (terms, narratives, folklore, ethnocosmography, popular meteorology, relics of lunar calendar, folk belief, etc.) than about other heavenly bodies.
\end{abstract}

Keywords: ethnoastronomy, folklore, Lithuania, lunar calendar, Moon

\section{THE NAME OF THE MOON AND ITS ORIGIN}

The common terms used for the Moon are Menulis and ménuo. The word ménuo means at the same time the celestial body, the Moon, and the time period of a month. These names directly derive from the Indo-European root *menes-, *men( $n$ )s-, 'moon' and 'month', and have a more general meaning of *me- 'measure' (DSS 54). So, in the past, the Moon was used as the natural cosmic instrument of measuring time.

It must be separately noted that Lithuanians residing in Belarus in the ethnic areas of the Lithuanian population in some places refer to the Moon as Dievaitis (in dialect Dievaicis) 'young god, the son of God'. Often the word is uttered in the diminutive form. In Pelèsa they say: Dievaiciulis (recorded by the author in 1991, also cf. LKŽ K), Dievaitukas (LKŽ II 515). In Radūnai area-Dievaitulis (LKŽ II 515), Devaitulis, Deveitulis, Deveitulis (TD IV 171, 178). Lithuanians of Pelesa (Voranava region, Khrodna area, Belarus) and the Lithuanians of the area have referred to the Moon in these terms until now. The same word is used for the time measure - a month. The native population believes that the word Menulis entered the colloquial language use from the written sources and the schools. We may assume that the Moon was referred to as Dievaitis on a much wider territory and were adopted from the remaining prayers 
addressed to the waxing crescent moon. In these the Moon is referred to as jaunikaitis 'young man', karalaitis 'young king' but also as Dievaitè lis 'Dear God', Dangaus Dievaitis 'Heavenly God', Sūnus Dievo ‘God's Son', Dievas Sūnus 'God Son'. In an archaic traditional Lithuanian polyphonic song, recorded in 1937, the new moon was named Dieva sūnelis 'the young son of the God' (Slaviūnas 1958: 194). In prayers and narratives the Moon is occasionally referred to as Dievas 'God' (Balys 1951: 19-20; Vaiškūnas 2002: 373374). These facts should be considered the remains of the former worship of the Moon.

Very few narratives about the nature of the Moon have been recorded, and even these are sparse and fragmentary. It is said: Ménulis yra žemé ('the Moon is the Earth'), tokia pat žemé [kaip ir $m \bar{u} s u$ ] ir ten gyvena žmonès ('the Earth like ours with people living on it'), also kažkoks akmuo ('some kind of a stone'), sustingęs kamuolys ('a frozen ball') or else užšalusi Saulè ('the frozen Sun'), occasionally naktinè Saulè ('the night Sun'), nakties šviesa ('the light of the night'), naktine Dievo Lempa ('the night lamp of God'), Dievo akis ('God's eye'). It has been considered that the Moon is Saules pagalbininkas ('the Sun's assistant') that shines instead of the Sun at night or that the Moon is big fire burning in the God's palace and moonlight is the light shining through the windows of the palace (the stars). There also is a record according to which the Moon is the velnio namai ('the House of the Devil') because it is the place where the Devil resides. Before World War II in Šiluva the following story was recorded: "Devil borrowed a sieve from Mary. He didn't want to carry it to the heaven so he threw the sieve up and the Moon appeared" (SBK).

There are some explanations for the spots on the Moon. People believe the spots form a face with a nose, eyes and a mouth. In full moon a woman or a girl carrying water buckets with yokes can be seen. It is narrated that the Moon took an orphan girl, which asked his help. Sometimes it has been said that the Moon punished a proud girl and took her to himself. It is also believed that in the Moon we can see the legendary Lithuanian wizard Tvardauskas, whom the devil took to hell but lost on the Moon, also one may see the scene of the first fratricide on the moon: Cain holding his slain brother Abel on a pitchfork (Balys 1951: 9-11). 


\section{PHASES OF THE MOON AND ITS PATH}

The period of the changing of the Moon's phases was divided in two main lunar phases -jaunas 'young' (Waxing Moon) and senas 'old' (with or without adding the word Mènulis 'Moon') (Waning Moon), which were further separated from one another by-tuščias 'empty' (New Moon) and pilnas 'full' (Full Moon) phases (Fig. 1, F1).

Very often the two main moon phases already mentioned were divided into further parts. In this case jaunas 'young' is the Moon before the first quarter (Waxing Crescent) and senas 'old' is the Moon before the last quarter (Waning Gibbous). Moon after the first quarter is called priešpilnis 'almost full' (Waxing Gibbous). Moon after the last quarter is called senagalys 'old-end' or delčiagalys 'wane-end' (Waning Crescent). In this case the cycle of the Moon is divided into six phases (Fig. 1, F2).

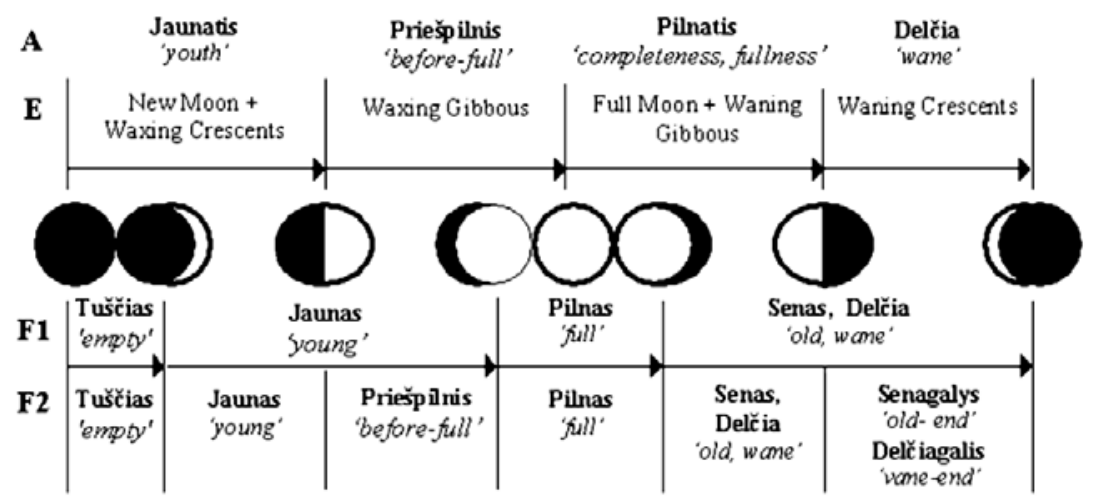

Figure 1. Phases of the Moon and their Lithuanian names: A - the appellative names in the literary language, $E$-English equivalents, F1, F2 - the folk names.

The beginning of the 1st phase-jaunas 'young' is considered the appearance of the crescent of the Moon in the western part of the sky after 2-3 days when the Moon was not seen. When the disk of the Moon becomes bigger, it is said that the Moon auga 'grows'. When it becomes the crescent, the second phase starts, which is called priešpilnis 'almost full' (Waxing Gibbous). When the Moon becomes a circle (full) it is already pilnatis 'fullness', pilnas 'full' (with and without the word Ménulis). Very often it is pointed out 
that the full moon is when the Moon rises immediately after the Sun sets down and vice versa. However, when the Moon does not set before the sunrise its disk wanes and the full moon is over.

When the disk of the Moon starts getting smaller (Waning Gibbous), it is said that the Moon dyla 'wanes', eina i sena 'goes old', and in Žemaitija (western Lithuania - Samogitia) it is said to dyla, blanksta 'wanes, fades'. This phase called delčia (a noun which is derived from the verb dilti 'wane') or senas 'old' (with and without the word Menulis). In Žemaitija the beginning of this phase is called paraiža, paraižos (a derivation from the verb réžti, raižyti 'cut', i.e. 'what is left after cutting'). In Dzūkija (southern Lithuania) it is called padaužos (a noun derived from the verb daužyti 'to break', i.e. 'that which is left after breaking').

It is narrated that the risen Sun finds the Moon in the sky and chips off a part of it. Then in the evening, when the Sun sets, the Moon does not rise soon. The dark nights are coming. In this case in southern Lithuania and in Belarus on the ethnic territories of Lithuanians it is said that the Moon vakaroja 'has/spends its evening time'. In northern Lithuania it is said that the Moon patinkst, aptingsta 'becomes lazy'.

Half-moon (in the last quarter) is in some places called pusdailis, pusdylis 'half-wane' and in the East Prussia at the beginning of the century was referred to as dalgakynos (a derivative from the word dalgis 'scythe'). Moon after the last quarter is called delčiagalis 'wane-end' or senagalis 'old-end' (Waning Crescent). The period when the Moon disappears, the two-three days of invisibility, is called: tuštuma 'emptiness' (phonetic variants of tuštumas, tuštumai, tuštymai, etc.); tuščias 'empty' (with or without the word Mènulis). In east Lithuania this phase is also called dykuma 'emptiness'. In west Lithuania it is known as tarpijos (a derivation from the word tarpas 'interval' - interlunium).

When referring to the changing of the phases of the Moon the words used are: keičiasi 'changes', mainosi 'alternates', verčiasi, persiverčia 'turns', 'turns over'. The periods of the change of the Moon are also called: sqquartai, squvartos, squarta, sąnvarta, suvartai, apyvarta, apyvartos 'turn, turn over', mainai 'exchange', sugriuvimas 'collapse', pairimas 'disintegrating'. 
Until nowadays, the answers to the question: "Why the Moon is changing?" contain the echo of the archaic view that holds the explanation associated with the movements of the disk of the Moon behind a certain rock or a mountain.

In 1994 in the area of Šalčininkai, a story about three brothers who once split the Moon was recorded. The story goes that the three brothers found a round moon in the forest. When one brother died he cut one third of the moon and had it placed in his coffin. When the second brother died, he cut the second part and the third brother took the third part. This is how the night turned dark (LKAR 2/517521/). This story reminds a primitive view that when the Moon disappears it gets to the world of the dead and shines there.

There are stories explaining the changing of the phases of the Moon with to the movements of the Sun and the Moon. In Dzükija it is said that the Sun and the Moon began to argue which one of them is faster. They began to race. The Sun outrun the Moon and left it behind. While outrunning, the Sun jumped over the Moon and broke its edge. Having jumped over the Moon again and again the Sun broke the Moon completely (LKAR 2/1-3/).

The explanation that the Sun is the reason of the Moon's getting smaller is widely spread in Lithuania. It is said that the Sun pagauna, užtinka, užkabina 'catches' (daužo 'beats', atdaužia 'chips', atkerta 'severs', atima 'takes away', grèbia 'takes', temdo 'darkens', dalina 'segments', mažina 'decreases') the Moon. In the morning before sunrise when only a thin scythe of the Moon (senagalis) can be seen, it is noted that Saula Menesi ima 'The Sun takes the Moon', and the next day the Moon is not seen at all (Baukevičius 1994).

Judging from the ethnographical material we can see that rural people were familiar with the movement of the Moon through different phases. It was noticed that the paths of the Sun and the Moon in the sky change. Villagers knew that in winter the Moon followed the summer path of the Sun (high), and in summer followed the winter path of the Sun (low).

Attention was paid to the planets wandering near the Moon's path. Unable to distinguish one planet from another gave rise to the be- 
lief that the same star (planet) appeared near the Moon. That star was called Žvaigždè Mènesio 'Moon's Star' or Tarnas Mènesio 'Moon's Servant' (DSPO 163).

\section{THE MOON AND THE AGRARIAN CALENDAR}

The solar cycle was the main phenological indicator, but the Moon variations were also very important in the life of farmers. Even nowadays, the alternation of moon phases is considered quite important in folk tradition - the phases are usually related to favourable and unfavourable time periods. The majority of rural population still strongly believe that various agricultural activities should be coordinated with the different Moon phases (Balys 1986). Whatever is started while the Moon is waxing is supposed to grow and proliferate too, while what is started during the disappearance of the Moon decays and shrinks as well. Therefore the time of the waxing crescent is sometimes called dosnus 'generous', while the waning Moon is called šykštus 'skimpy'.

The popular opinion about favourable and unfavourable moon periods is worth explaining here in more detail, because such attitude obviously demonstrates an archaic attitude towards the natural environment and time. The analysis of abundant but conflicting ethnographic data about the coordination of various agricultural activities with the Moon phases shows some general regularities in the popular categories of positive and negative aspects of the Moon phases (Vaiškūnas 2006: 174-176).

The Waxing Moon is supposed to be favourable to the growth in general and for any starting processes. Still up to day, we observe important variations in the accepting of the beginning and end of this period:

1. While the Moon grows from a thin crescent to the first quarter (Waxing Crescent) all starting processes will undergo a strong growth. They say that during that time the growth of stems, leaves, and blossoms is very intense, and that even foundation stones under construction, come up to the surface. This period is associated with strong growth, proliferation, humidity, liquidity, and at the same time tenderness, softness, and vulnerability. 
Though active vegetation takes place, it is not fruitful. It is a favourable time for various pests.

2. The growth of the Moon from the first quarter to the full Moon (Waxing Gibbous) is also favourable to all growing processes but this time it will also be fruitful, leading to full-fledged formation of the fruit to maturity.

At the Waxing Crescent mostly cereals and especially summer corn were sowed, flowers were planted or replanted. Also hair was cut, sheep were sheared, hay and clover were mowed (expecting to grow back soon), hens were let to hatch (expecting more hens than cocks), cows were coupled (expecting heifers), etc. But because of the abovementioned reasons a lot of things were prohibited during this period. It is not advisable to sow leguminous plants, hay and many other vegetables, because people were afraid that they would bloom long and would not give good fruit and become infested.

This was an unsuitable period for:

- storing the crop in the granary and threshing because the grain would be infested with rats;

- building structures, laying fire stoves, cleaning chimneys, digging new and repairing old wells (because they may be raided by different parasites);

- making and cleaning clothes, taking baths (the body would grow itchy and become lousy);

- spinning (because the thread would not be strong);

- weaving (because the thread would be uneven);

- slaughtering pigs (the meat would not keep and rot soon, also would lose the taste);

- pickling cabbage (because it would be soft, slimy and rot quickly).

Besides it was believed that the cattle born during the period would be weak, scared, grow slowly and be not suitable for breeding. A cow that is born in the new Moon may be easily cast spell by the wicked eye and give little milk. A child born during the new Moon stays young for a long time, but is not resistant to diseases, to bad spells and is shy. 
In the second half of the first period when the Moon is waxing towards the half-moon phase the processes started on the Earth also develop in the same line but the growth becomes more prolific and yields worthy and mature fruit. The job started at this period is oriented towards favourable completion and plants give mature fruit. It is recommended

- to cut crop and take it to the granary (because it would guarantee full depositories and there would be an abundance of crop through the whole year);

- make nets, catch fish (because the nets would be full);

- make traps (because they would catch birds, weasels and rats well);

- to pick eggs for hatching (hens would be larger);

- to make nests for hatching and let the hen hatch (all the eggs would be full and the shell would break easily);

- to spin and weave (the work would proceed easily);

- to bleach the cloth (it would be white as the full Moon);

- to couple the cows (because they would be fertile);

- to plant vegetables (because the harvest would be good);

- to slaughter pigs (the meat would be tastier, and would expand during boiling).

In conclusion it is marked that the half Moon is a good time for all farming activities because everything will take a good turn.

The Waning Moon is associated with decay and wane; also, its first and second parts are somewhat different:

1. It is a common belief that the period of shrinking of the Moon from the full Moon to the last quarter (Waning Gibbous) is the least favourable to start anything. Everything started during that period is condemned to decay.

2. The period that starts after the last quarter (Waning Crescent) presents certain positive aspect of the waning process. Therefore the last crescent is again regarded as a favourable period for all activities bound to conservation or even sterility. 
It is a time to prepare food for conservation, to cut wood, to salt or smoke meat, etc. It seems as if an additional force pointing downwards came to action, and therefore offers also favourable conditions for planting beets and root vegetables, so that they would gather their energy underground.

Towards the end of the month when the Moon vanishes from the sky for two or three days, there is a period which is believed to be a "time in vain" and any work would be done in vain, i.e. would give no results (Vaiškūnas \& Lovčikas 1999).

Although the entire second period is oriented towards waning and weakening, separately taken the phases of the period are distinguished by certain peculiarities. Often it is considered that the waning of the Moon since the Full Moon to the third quarter of its full phase is the least favourable period to start any activities. Everything that is done during this period is deemed to disappear and wane. Yet the period that starts after the third quarter of the Moon phase gives some constructive power to the waning. Therefore the crescent of the waning Moon (senagalys, delčiagalys) is again considered favourable to all undertakings. The works started during this period are oriented towards preservation or to sterility. For example, the meat of the slaughtered pig keeps long, worms do not raid it and the buildings started at that period remain uninfested by parasites. Besides it is believed that the plants put in the ground in this period grow under the ground, i.e. their root system becomes stronger, tubers grow well (this is the time to plant potatoes, turnips and others). It appears as if some downward drawing powers of the Earth suddenly start to emerge. It is even believed that the basement stones for the new building lain down during the period sink deeper into the Earth (cf. the earlier belief about stones rising out when laid during the new Moon).

When the Moon is waning it is recommended:

- to plough fallow, to turn stubble-field (the old rye would not be eaten by worms, no weeds would grow, the roots of rye would be better);

- to plough the soil for the winter crops (because the turf would quickly rot); 
- to bring the crops into the granary because mice would not attack them;

- to build houses, to build fireplaces (no vermin or parasites inside);

- try to plan hatching for that period (because all the birds would be resistant to diseases);

- air the wardrobe (to repel moths).

- to take bath (the body would not itch, and have no lice);

- to build barrels (they would not be eaten by parasites), etc.

Last Friday of the period is considered the best time for cleaning a place from parasites.

Unfavourable time for planting the summer crops and the vegetables is the period when the Sun and the Moon meet in the sky. It is believed that the summer crop planted in the period will grow empty and the vegetables will go into blossom but will bear no seed.

As we can see, the observation of the phases of the moon did not only mark calendar time, but also indicated some sort of time quality. Though it is now often heard that the phases of the Moon "have an effect", namely that they influence various phenomena, folk tradition does not speak of any direct physical influence of the Moon.

It seems that the old popular tradition depicts the Moon not only as a time marker or even a time factor but also as a quality mark for certain time periods. But all this is difficult to establish with any certainty, because it has been also often observed that the favourable and unfavourable Moon periods are completely parallel with menstrual cycles. Is the general symbolism of growing in the nature accordant with the visible aspect of the Moon? Or is it rather that a certain time has a growing quality influencing the whole of nature including the Moon? In fact, such logical questions have no object in folk culture, which is based only on direct observation and logical-symbolical classification. This is confirmed by the general confusion manifest in all Indo-European languages between the categories of chronological time and weather conditions (Vaiškūnas 2006: 174-176). 


\section{THE MOON AND THE WEATHER}

In the attempt to predict weather for the coming month people observed the appearance of the Waxing Crescent. If the crescent turned pink on the third day, they said that the month would be rough and windy, if it turned dark, rain was expected. If the crescent was white and curved and both of its ends sharp and small the weather would be nice. If the crescent was almost straight the month would come overcast and foggy. But if around the Waxing Crescent light bands would be visible, the month was expected to bring storm and bad weather. Also it was known that the weather on the fourth night of the new moon would be about the same as in the rest of the month (DSPO 203). Also it was noted that on the fifth day of the waxing crescent the weather was very windy (SUKB 49).

The weather prognosis was also determined by the crescent's inclination relative to the horizon. If the crescent appeared to stand vertically, good weather was expected. If the crescent was inclined towards the horizon, the weather would be rainy.

According to a prevailing opinion, the weather changes together with the changing of the phases of the Moon. If the weather does not change at the turn of phases, similar weather is expected for the coming phase. It is said that the newborn Moon has to wash itself. That is why rainy weather is expected at the waxing crescent.

When a corona or a halo appears around the Moon it is said that the Moon is apsitveręs 'has enclosed itself' or the Moon is surrounded by ratilas or drigne 'a circle' i.e. halo. Then, precipitation is expected soon. If the circle is close to the Moon, then the precipitation will come soon, if it is at some distance from the Moon the precipitation will come later within about a three-day period. Judging from the materials written down in the 19th century there was a difference between the corona and the halo. If the corona was seen, good weather was predicted, if a single or a double halo precipitation would come (SUKB 48).

Some data allow us to think that the Moon was considered to be the antipode of the Sun. If the Sun rises high up in the sky in sum- 
mer and emits warmth, so the does Moon rise high in winter and chills the Earth (TD III, 59-60).

\section{THE INFLUENCE OF THE MOON ON HUMAN BEING}
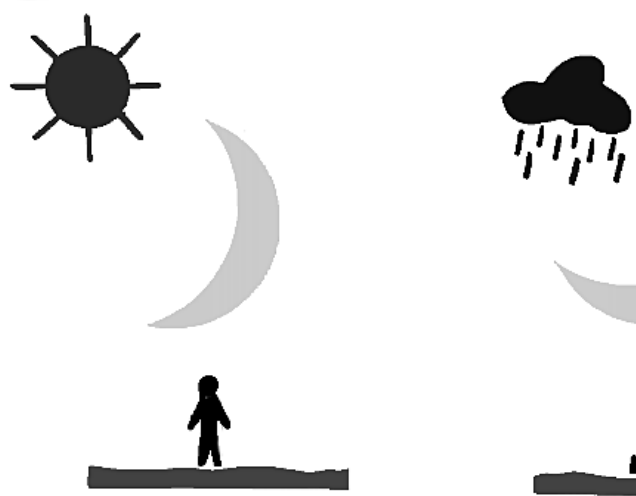

Figure 2. Position of waxing crescent and its influence on weather and on man's health.

Quite a number of facts show that it was believed that the Moon has a strong influence on human beings. Even nowadays there is a strong belief among village people that the light of the Moon falling through the window (or through a slot or a hole in the window) might harm a sleeping man and especially a child or a pregnant woman. Then the person was believed to turn lunatic and feel weightless or even without the physical body and walk along the strangest of places: on rooftops, the surface of water and may walk through fire without catching fire (Dunduliene 1975: 259). It was said that when the Moon and the Sun are both in the sky it was forbidden to make a child laugh, because his navel would hurt (BPK 486).

It was believed that illness and attacks tend to recur for the sick during the waxing crescent and the angle of inclination of the new Moon towards the horizon determined not only the weather of the new month but also a person's health in the coming month. If the 
crescent was inclined in the manner resembling a boat it was believed that the month would bring death, especially in autumn (Figure 2).

There is a good deal of evidence demonstrating the survival of the traditional belief that the phases of the moon predetermine the character, appearance and health of a new baby (Vaiškūnas 1996: 158-166). Researchers into the Lithuanian ethnic culture such as J. Balys (Balys 1951: 13), P. Dundulienè (Dundulienè 1975: 258; 1988: 38-39), and A. J. Greimas (Greimas 1990: 171-173) also paid attention to the influence of the moon on a living individual.

The influence of the moon on a baby before its birth. It has been believed that events happening well before the time of birth have an influence upon the nature of a baby. This is clear from a variety of evidence. First, the phase of the moon on the parents' wedding day is of great importance. If the wedding takes place when there is a waxing crescent in the sky, the children of the couple will be "pretty; not tall; the first baby will be a girl" (SBK). If it takes place at full moon then "the family will be large and healthy" (SBK; Śliavas 1993: 130). Latvians believe that a woman married during the waxing moon "will get pregnant soon" (Straubergs 1944: 285).

The phase of the moon at the moment of sexual contact is also important. In the Latvian tradition we find evidence that the gender of a baby depends on the phase of the moon at that particular moment: "[people say:] if sexual contact occurs during the waxing moon, a boy is born, and a girl is born if the contact occurs during the waning moon" (LTT 14781).

Another important factor is the parents' behavior before the sexual contact. It is prohibited for a man to urinate in front of the moon, because he may lose his potency. And if he has sexual contact immediately after that, an abnormal child or even "a devil might be born" (SBK; LTA 790/21/; LKAR 2/156/; 2/388/; 2/447/). The same is said to apply for women (SBK). People believed that moonlight could have an impact on the health of a baby. "If moonlight falls on a sleeping pregnant woman then her baby might be born a sleepwalker or even anemic" (SBK). 


\section{The influence of the moon on a baby at the moment of its birth.} It is believed that the nature and health of a man are determined by the phase of the moon at the time of his or her birth. Ethnographic data indicate the characteristics of a man born at a certain phase of the moon, and these are summarized in the tables that follow. Positive qualities are italicized. The figure next to each characteristic feature shows the number of places where it is mentioned. The sources used are listed after each table.

Children born during the waxing moon:

$\begin{array}{llll}\text { look young } & 22 & \text { are angry } & 2 \\ \text { are afraid of eyes } & 12 & \text { are clever } & \text { are happy } \\ \text { are timid } & 9 & \begin{array}{l}\text { eat a lot } \\ \text { are joyful and grow up well }\end{array} & 2 \\ \text { are nice } & 8 & \begin{array}{l}\text { have teeth that grow } \\ \text { are weak }\end{array} & 2 \\ & 6 & \begin{array}{l}\text { faster and more easily } \\ \text { do not live to a }\end{array} & 2 \\ \text { cry at night } & 4 & \text { venerable age } & 1 \\ & & \text { are tall } & 1 \\ \text { are resistant to illnesses } & 4 & \text { are lazy } & 1 \\ \text { are frivolous } & 3 & \text { are energetic } & 1 \\ \text { are strong } & 2 & \text { L }\end{array}$

(Sources: SBK; EAA 93100; LTR 4232/61/; LTA 1252/73/; EAA 88080; EAA 89010; Šliavas 1993: 118.)

Children born during the waning moon:

$\begin{array}{ll}\text { get old soon } & 20 \\ \text { are angry } & 5 \\ \text { are strong } & 5 \\ \text { are slow and not nimble } & 4 \\ \text { are sad / gloomy } & 3 \\ \text { are not nice } & 3 \\ \text { thin } & 3 \\ \text { are unhappy } & 2 \\ \text { are unhealthy / fall ill often } & 2 \\ \text { do not live long } & 2 \\ \text { (Sources: SBK; EAA 93100; EAA } 11)\end{array}$

$\begin{array}{ll}\text { are quiet } & 2 \\ \text { are not afraid of eyes } & 2 \\ \text { are clever } & 2 \\ \text { are brave } & 2 \\ \text { are practical } & 1 \\ \text { live long } & 1 \\ \text { are serious } & 1 \\ \text { are lazy } & 1 \\ \text { are hypocrites } & 1 \\ \text { grow up bad } & 1\end{array}$


Children born at full moon:

are nice and plump

are very strong and healthy 3

are wealthy, happy and live well 3

are very clever 1

are lazy 1

(Sources: SBK; LTR 4232/55/; LTR 4232/61/; EAA 93100; EAA 89010;

Šliavas 1993: 118.)

Children born during the waning crescent:

live badly

(Source: EAA 89010.)

Children born at new moon (emptiness):

are greedy

(Source: EAA 93100.)

The Latvian tradition includes quite a lot of information about the influence of the moon on a newborn baby. Latvians believe that children born during the waxing of the moon:

look young for a long time, do not turn grey (LTT 2417, 2418, 2419, 2420, 2422)

are healthy

(LTT 6856)

are nimble and joyful until old age

(LTT 2417)

are happy

(LTT 2421, 2483)

The ones who are born during the waning of the moon:

turn grey and get old soon

lose their teeth early

are not nice

are gloomy

die more often

[boys] usually remain bachelors / [girls]

become old maids

People born at full moon:

are the wealthiest
(LTT 6856, 2424, 6847)

(LTT 6856)

(LTT 2484, 2423)

(LTT 2417)

(Straubergs 1944: 263)

(LTT 6856, 6848, 19831)

(Straubergs 1944: 263) 
The influence of the moon after birth. The cycle of lunar phases continues to influence the life of children after their birth. Certain things should be done at the corresponding phase of the moon. For instance, a child baptized during the waxing moon has the following qualities when he or she grows up:

remains young for a long time

is healthy

is honest, happy, and wealthy

is joyful

is nice

\section{8}

1

1

1

1

A child baptized during full moon:

is very strong

A child baptized during the waning crescent:

is unhealthy

is strong

1

(Source in each case: SBK.)

The phase of the moon was also important when weaning a baby from the breast. According to P. Višinskis, the Samogitians weaned a girl on the third day of the waxing crescent so that she would "not get old and remain young for a long time". A boy was weaned in the first quarter or at full moon in order to keep him "healthy and full like the moon". Some mothers weaned their boys in the last quarter of the moon wishing their sons "not to be adventurers in love" (Vishinskii 1935: 151). If a boy was weaned from the breast in the waxing moon then "he would run after girls even when he was old" (EAA 94010). (Latvian traditions contain the same belief (Straubergs 1944: 263).) Girls were also weaned during full moon in the expectation that they would be "full and nice" (EAA 94010). The author of the report noted that if a married Samogitian woman had a girl and she wanted her second child to be a boy then she had to wean her daughter from the breast on the third or fourth day of the waning gibbous (i.e. 34 days after full moon). If she did so in the waxing phase then she would have another girl. 
The behaviour of a grown man in accordance with the lunar phase cycle continues to influence the fulfilment of his fate. The phase of the moon is important, for example, when matchmaking, getting married, or even building a house. This means that it is possible to influence fate by choosing a certain time for a given action. However, it was also supposed that the more an adult depended on his parents, the more did this dependence finally take its effect at the time of their death. It was believed that dying parents could take away the good fortune of their children. The phase of the moon on the day of death determined the future of children. For instance, if father or mother died at full moon, they would "leave happiness to their children"; the children would "live happily and would do not lack anything, their homes would not grow poor"; and sons would "get rich" after their father's death. If a father died in the waxing phase of the moon, they say that "the family would get richer", or "a son would gain riches" until he grew up. The same happened to daughters if their mother died in the waxing moon. If a parent died while the moon was waning, their children would become unhappy: "they would start living hard, their riches would keep vanishing, their homes would get empty, and they could die early" (Balys 1981: 43). The same belief is confirmed in the Latvian traditions (Straubergs 1944: 291-292).

Having examined the available sources, it is possible to assert that the following qualities of a person are determined by the phase of the moon in the most important moments of his or her life:

1. appearance (in $37 \%$ of sources);

2. health $(27 \%)$;

3. character $(26 \%)$;

4. wealth $(5 \%)$;

5. happiness $(4 \%)$;

6. other $(1 \%)$

1. The appearance of a person is defined quite directly: the waxing moon is usually linked to a pleasant and youthful appearance, and the waning moon, conversely, brings about an unsightly and aged appearance. It is interesting that the name of the waxing and the waning phases of the moon correspond to the main periods of a person's life in Lithuanian and Latvian languages. The waxing phase 
of the moon respectively in Lithuanian and Latvian is called jaunas and jauns it means 'young', the waning phase - senas and vecs it means 'old'.

2. The statements concerning the influence of the waxing moon on person's health are rather contradictory. On the one hand it is said that those who are born during the waxing phase of the moon are "afraid of eyes" (12 sources), weak (6), and cry at night (4), but on the other hand they are resistant to illnesses (4) and strong (2). It seems that the weakness of those who are born when the moon is waxing manifests itself not in poor health, but in their lack of resistance to other people's negative influences. In other words, those who are born during the waxing moon are weak because they might be easily affected by other people's "evil eye". It is supposed that children cry at night for the same reason. Babies who are born during the waning moon are strong (5 sources) and not afraid of "evil eye" (2), but they are not healthy and are often ill (2).

3. The characters of people born during the waxing and waning Moon are clearly differentiated. Joyful (8), energetic (1), and good natured (2), though timid (9) and frivolous (3), people are born during the waxing moon; whereas sad and gloomy (3), and angry (5), though brave (2), serious (1) and practical (1), people are born during the waning moon.

On the whole, babies who are born during the waxing moon have more positive qualities, with the ratio of positive to negative characteristics being 12:8. For children born during the waning moon this is reversed: 8:12. Positive qualities linked with the full moon exceed negative ones by $4: 1$, although very few examples are recorded.

We can see that the changing phase of the moon is believed to modulate processes in the natural world and, as a result, there are favourable or unfavourable times for several of these processes. Yet the fate of a man, a plant or an animal is not considered to be fatalistic or finally fixed at the moment of birth. A man born in one or another period can influence his fate by carrying out the most significant activities of his life at a particular time. This can happen whether the timing was intentional or not. If, for example, a baby has been born at an unfavourable time, it is possible to give him the 
desired qualities by baptizing or weaning him from the breast at a certain time. For this reason, people who wanted to preserve a child's beauty and youth tried to baptize him during the waxing moon if he had been born during the waning moon (Dunduliene 1975: 258). Likewise, if it was desired to increase a baby's weight he would be weighed during the waxing moon (SBK).

\section{MOON WORSHIP}

According to written sources of the 18th century, bread, wool, flax, and money were sacrificed at a sacred stone with footprint in the time of the Waxing Crescent. That was done asking to regain lost health and first of all - the strength of one's feet, eyes, hands (Lebedys 1976: 210).

We can see traces of moon worship in a popular opinion that it is not allowed to point at the Moon with one's finger and it is wrong to urinate in front of the Moon. It is believed that by pointing your finger at the Moon with the finger you risk to cut your finger later, it may wither, go bad, and decay. It is also believed that one's arm may wane or get paralyzed, that you may go blind or some other disaster would befall you, that you would be carried by the Moon in your sleep or else that you would stick your finger straight into the God's eyes.

Both in the past and now, Lithuanian villagers orientate their stores according to the appearance of the Waxing Crescent. There are numerous prayers to the Waxing Crescent which sound very ancient. Upon first seeing the crescent of the waxing Moon, the person stops, turns to face it, removes his hat, bows and sometimes goes down on one's knees and says an old prayer. Owing to the influence of Christianity, a person often makes a cross-sign (most often not with bare hand but with hand tucked in the long sleeve, a flap of the jacket or a handkerchief), sometimes three Hail Mary prayers are said. Then while addressing the Moon people most commonly pray for health, beauty, youth, merriment, wealth, happiness and fortune, the posthumous heavenly abode or the kingdom of the Perkūnas (the Thunderer) (Greimas 1990: 172-173). Here are some examples: 
Mènuo, Mènuo, Mènulèli,

Dangaus šviesus dievaitèli;

Duok jam ratu

Man sveikatu

Duok jam pilnysti,

Man Perkūno karalystị.

(Balys 1951: 11)

Karaliau, karaliau,

Dievo sunau,

Tau šviesybè ant dangaus,

Man linksmybè ant žemes.

Tau ant pilnaties,

Man ant sveikatos.

(Dundulienė 1988: 40-41)

Tegul bus pagarbintas

Švies Mènesélis.

Tau šviesybe,

Man gražybe;

Tau dievyste,

Man žmogyste.

(Balys 1951: 12)
Moon, Moon, dear Moon,

Bright little God

You should be come round

And I will remain healthy,

Give him the fullness

And me the realm of Perkūnas.

King, king,

The Son of God,

Lightness for you in the sky,

Joy for me on the Earth.

Full Moon for you,

Health for me.

I bless you,

Bright dear Moon.

I wish brightness to you

And give beauty to me;

I wish you divinity,

I ask from you humanity.

Also there were prayers to protect against different disasters:

Jaunas ménulaicis.

Dangaus karalaicis,

Sergèk, gink nog ugnies degimo,

Nog vandenio skendimo,

Nog dantu skaudejjimo.

(Dundulienè 1988: 40"41)
Young Moon,

Prince of the sky,

Guard, protect from burning in fire, From drowning in water, From toothache.

The New Moon was asked to cure warts, birthmarks, sometimes herpes and tumours. Then the Moon was addressed as follows:

Jaunas Mènuli,

Dangaus karaliau,

Apšieti žemę apvalai,

Apvalyk ir mano griešną kuną.

(Masalskienè 1990)
Young Moon,

King of the sky,

You light the Earth and clean it,

Clean my sinful body too. 
Then it may help to clean the face with a white handkerchief to make it as bright as the Moon. It is also recommended without moving from the place where you happened to mark the Moon and without removing the eyes from the heavenly body take some soil from under your feet (gravel, snow, whatever happens to be there) rub the warts and throw behind with the back of your hand. Then the warts will disappear. Others pour water on the hands and say: "I wish to be as clean as you are clean". If one has no water on the spot, one has to shout for someone to bring it, because the warts attacked him or her (Balys 1951: 11-13).

Similar treatment is recommended for toothache. On seeing the Waxing Crescent the bad tooth is covered with the thumb of the right hand and then it is said while looking at the sky: "I now see the young Moon and bite my dead tooth" (Dundulien 1988: 42).

Young girls who wish to see in their dreams whom they would marry, in the above circumstances, have to fetch some soil from under the feet and put some into the scarf and, without speaking to anyone, go to bed. While taking the sand they have to say: "Young Moon, prince of the sky, let me see (in my dreams) who I will have to live with" (Balys 1951: 12).

Upon seeing the New Moon for the first time it is also important on what side was the Moon when a person noticed it. If it was on the right or ahead of a person, it meant that the month would be successful. If it was on the left - then the month would not be successful.

\section{RELICTS OF THE LUNAR CALENDAR}

Though Lithuanian chronology has unfortunately not yet been extensively explored and too little data about the old calendar systems have been collected, it is still believed that the Moon cycle was of common use. One of the proofs may be the description of a calendar stick explored by the 19th century Vilnius astronomer M. M. Gusev (1865: 335-354). 
This stick was found under the ground of the bank of the Streva River in the Trakai region dating to the 14th century. It is a stick with a copper-bound end and a spiral inscription (marks). The marks consist of many small nails (Figure 3, D). M.M. Gusev determined that the spiral markings represent twelve lunar months (Figure 3, A) and days of the week. Every month is marked with a different original sign and begins with the new moon crescent (Figure 3, F). M.M. Gusev found that the month marks depict phenological aspects of the months and the main agricultural works. According to his opinion, the year in this calendar starts with April (Figure 3, M). So the first month is represented by a descending pigeon (Lith. April - balandis 'pigeon'). Weekdays are marked according to the original local tradition of writing numbers, which is somewhat similar to the Roman (Figure 3, C).

In the Great Lithuanian Dukedom, already before Christianity, the Julian calendar was used together with both the Byzantine chronology (counting years since the creation of earth - annus mundi, or AM - 5,508 years before Christ), and the Roman era count (counting from the birth of Christ - anno domini, or AD). More conservative peoples continued to use the phenological and solar-lunar calendar for their agricultural needs much later. Lithuanian traditions of the 19th-20th century are rich in examples of coordination of solar and lunar cycles. Even recently recorded stories still tell about differentiating between "heavenly months" and "earthly months". It is said that the "heavenly month" starts before the earthly one, therefore it can be used to judge the upcoming calendar month:

"In the sky, months are counted. My mother knew that. Now the haymaking is coming but in the sky a different month comes. In the sky it is July, it is one month ahead. On the earth nobody cuts hay but the sky shows the haymaker. The sky month determines which one is coming on earth. Whether our month comes first, there is no knowing. When the sky showed the month with snow and rain, then we could see what month is coming"

(Mažrimas 1992). This statement refers to the fact that the beginning of the lunar month and its name may precede the beginning of the corresponding solar month. 

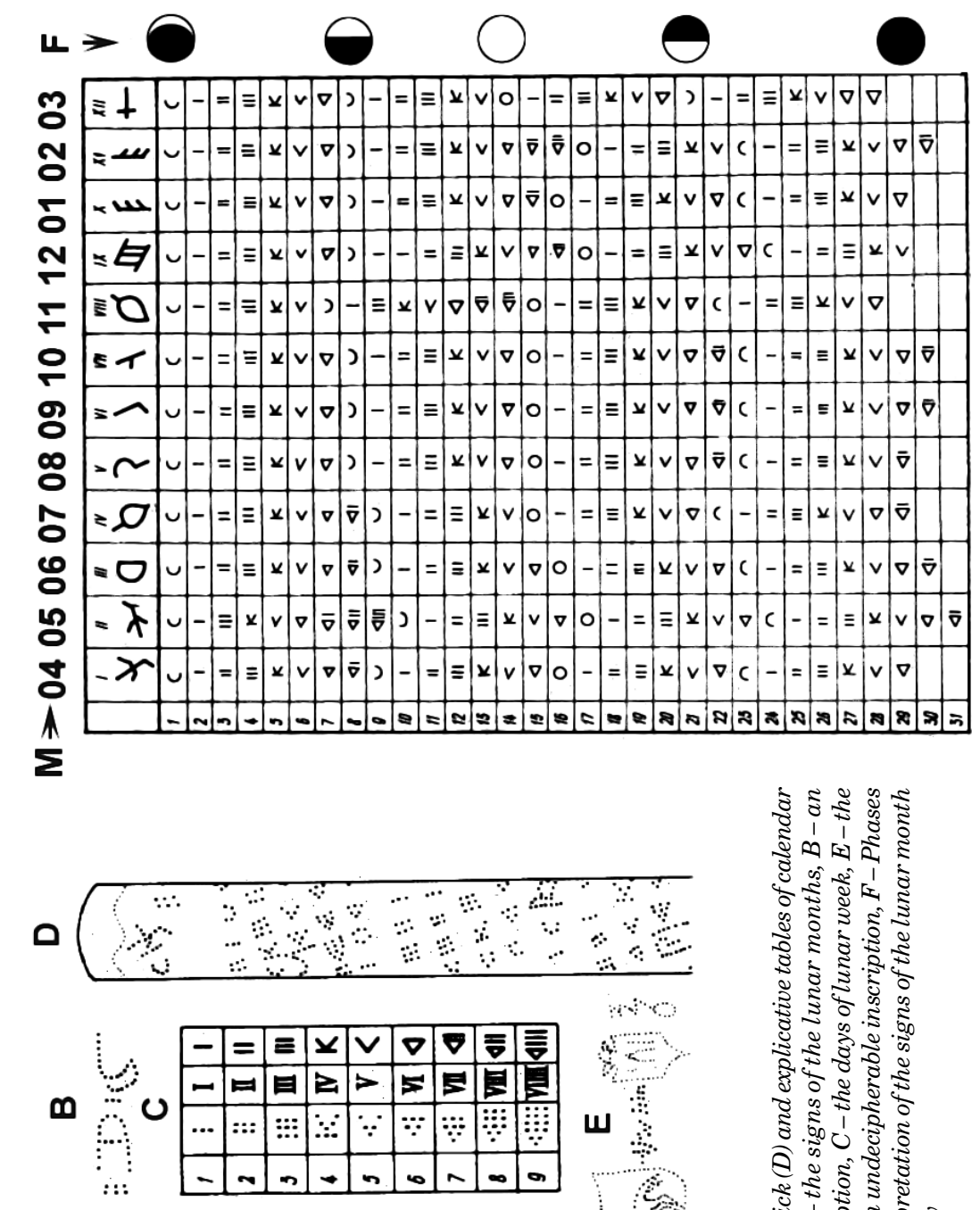

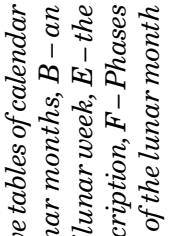

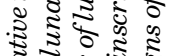

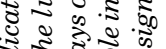

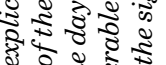

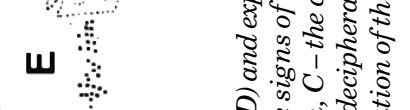

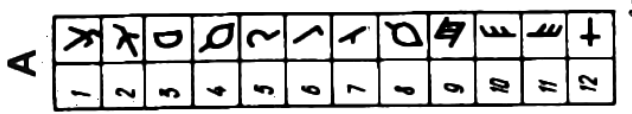

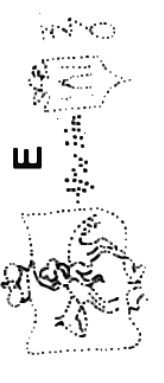




\section{THE MOON IN FOLKLORE}

Lithuanian riddles and fairy tales often associate the Moon with the Horse. In riddles it is called laukas arklys 'horse with the white frontlet or muzzle', kumeliukas aukso pasagom 'a foal with the golden shoes', dievo kumeliukas 'the foal of the God', occasionally called elnias 'a deer', jautis 'an ox'. In fairy tales the Moon, turned into a horse, rides along the sky and takes the hero to the maiden he is looking for (Greimas 1990: 51-56).

In Lithuanian folklore the Moon and the Sun are regarded as a married couple: the Moon is the husband, the Sun is the wife and the Earth or stars are their children. While explaining why the Moon and the Sun appear separately in the sky, it is often said that they quarrelled and divorced. There are two typical explanations for the cause of their enmity:

1. The Moon was not loyal to the Sun and started courting Aušrine (the Morning Star);

2. The Moon and the Sun could not share their daughter Žemé (the Earth).

In both cases Perkūnas 'the Thunderer' participates in the quarrel between the Sun and the Moon. In first story Perkūnas punishes the errant Moon by cutting it into two pieces. Sometimes it is said that the Sun herself leaves the Moon, hides from it or punishes it by beating or striking because the Moon fell in love with the Morning Star (Dundulienè 1988: 70-76). In second story Perkūnas separates the quarreled parties; he decided that the Sun should look at the daughter in daytime and the Moon at night. If both wish to see the Earth, then Perkūnas drives the other one away (Balys 1951: 89 ). Another variant from western Lithuania says that the quarrelling Sun and the Moon held a race. The winner was Sun and she was given the right to look at the Earth by day.

Analogous relationship between the Sun and the Moon is typical of Latvian folklore. J. Klètnieks has posed a hypothesis that the Latvian song motif in which the Sun is striking the Moon with a silver whip may be associated with the appearance of the half Moon in the neighbourhood of a bright comet tail. By his calculations the astro- 
nomic situation of this character was on 17 May, 240 years BC, when the Hale's comet was shining bright in the sky (Klētnieks 1986: 4047).

In Lithuanian folk songs the Moon is called 'Daddy' and the Sun is 'Mummy'. It is sung that the Sun is collecting dowry for the girl who marries and the Moon gives her dalis 'part, portion', dalia 'fate, portion' (i.e. gives her a part of his possessions). It is noteworthy that in Žemaitija one and the same word ryžti 'to rip' means the waning of the Moon and giving a part of one's possession to a girl to be married (LKŽ XI 775).

A.J. Greimas has analysed the role of the Moon in Lithuanian folklore and has found quite many arguments that the Moon could have been one of the sovereign gods in the Lithuanian triad of gods, next to Perk ünas 'the Thunderer' and Kalvelis 'the Smith'. According to him, the Moon could be responsible for life and death, health and beauty, for people's happiness and misfortune, wealth and poverty. In comparative studies into Indo-European mythology, this should correspond to the third divine function of godly sovereignty defined by G. Dumezil (Greimas 1990: 244-246).

\section{THE PLACE OF THE MOON IN COSMOGRAPHY}

It is believed that the Moon had to belong to the lowest cosmic sphere in Lithuanian folk cosmography (Beresnevičius 1990: 120122; Vaiškūnas 2005: 18-19). This opinion could be confirmed by some figurative cosmological symbols, such as the design of heavenly bodies carved on Valiulis stone (Moletai region) and symbolical structure of iron crosses (Figure 4) in which the crescent of the Moon is depicted in the lowest part of the composition. The Sun is located above the Moon and below the stars. In Lithuanian ethnocosmology the stars are related with souls (Vaiškūnas 1991: 35-37; Vaiškūnas 2005: 18-19). From the discussed material it becomes clear that it was believed that the Moon, most of all, influenced the material elements of nature. It is likely that the lowest position of the Moon corresponds to the lowest material symbolism of it. In this case the Sun takes an intermediate position between the stars and the Moon and joins the Moon (the material element) with the stars (the spiritual element). 

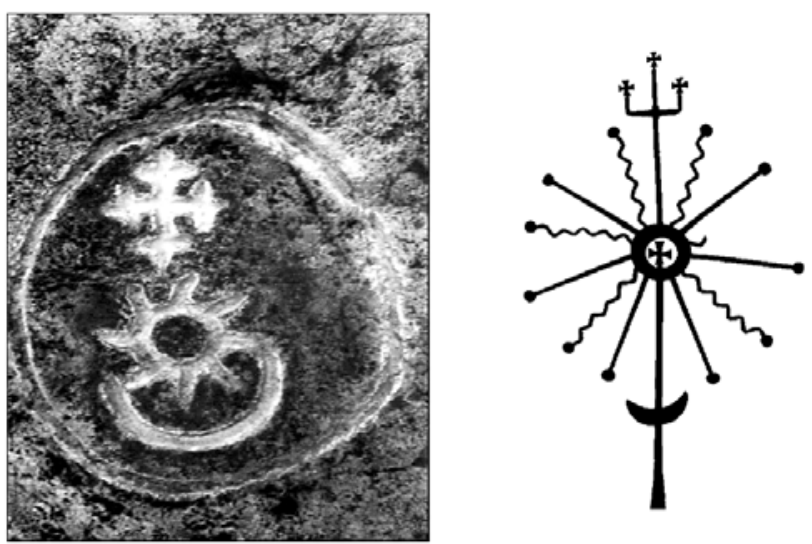

Figure 4. The Moon, the Sun and star(s) on Valiulis stone (MolPtai region) and on iron top of memorial monument (LLM MA Fig. 359).

Although the Lithuanian ethnographical material gives far more information about the Moon than about other heavenly bodies, we believe that the Sun and the stars were not less important than the Moon in the Lithuanian pre-Christian world outlook and religion. When the ancient system of knowledge was falling apart, higher transcendental layers of knowledge broke more rapidly while the lower levels, which played an important role in agricultural activities, remained longer.

\section{Abbreviations}

BPK - Mickevičius, V. 1926. Marcinkonių burtai ir prietarai. Tauta ir žodis. 4. Kaunas, 488.

DSPO - Davainis Silvestraitis, M. 1973. Pasakos, sakmès, oracijos. Vilnius.

DSS - A Dictionary of Selected Synonyms in the Principal Indo-European Languages by Carl Darling Buck. The University of Chicago Press.

EAA - Personal archive of ethnoastronomical material by J. Vaiškūnas in Kulionys village, Moletai region, Lithuania. This material was recorded during the period between 1988 and 2005.

LKAR - Archives of folk art at the Lithuanian Folk Culture Centre. Vilnius.

LKŽ II - Lietuviu kalbos žodynas. II. 1969. Vilnius.

LKŽ XI - Lietuviu kalbos žodynas. XI. 1978. Vilnius. 
LKŽ K - The card index of the Lithuanian Dictionary at Lithuanian Language Institute. Vilnius.

LLM MA - Stravinskas, A., Sakalauskas, M. (Eds.) 1992. Lietuviu liaudies menas. Mažoji architektūra. Vilnius.

LTA - Lithuanian folklore archives. The materials of this archive now belong to LTR (see below). LTA and LTR are distinguished in the article in order to help the reader separate older information (LTA information was recorded between 1935 and 1940) from more recent data (LTR information has been recorded since 1940).

LTR - Manuscript archives of Lithuanian Folklore in the Institute of Literature and Folklore at the Lithuanian Academy of Sciences. Vilnius.

LTT - Šmits, P. (Ed.) 1940. Latviešu tautas ticējumi. 2 sēj. Rīgā.

SBK - The Synopsis of Beliefs compiled by Jonas Balys from LTA (see above). This manuscript now belongs to the Department of Ethnology of the Institute of History at the Lithuanian Academy of Sciences. Vilnius.

SUKB - Szimtmetinis ukiszkasis kalendorius Briusa. Su praktikomis apie pagadas, siejimus wajsius, uztemimus Saules ir ménesio... 1859. Vilnius.

TD III - Tautosakos darbai. - 3. 1937. Kaunas.

TD IV - Tautosakos darbai. - 4. 1938. Kaunas.

\section{Informants}

Masalskienè, A. Born 1912, Marginiai village, Jieznas subdis., Prienai region. Written down by V. Musteikis 1990.

Mažrimas, Jonas. Born 1933, Pupėnai village, Kražiai subdis., Kelmè region. Written down by J. Vaiškūnas 1992.

Baukevičius, J. Born 1920, Nereikoniai village, Pakruojis subdis., Pakruojis region. Written down by R. Jurgaitis 1994.

\section{References}

Balys, J. 1951. Tautosaka apie dangu. Sodus. Michigan.

Balys, J. 1981. Mirtis ir laidotuves: Lietuvis liaudies tradicijos. Silver Spring, Md.

Balys, J. 1986. Lietuviu žemdirbystės papročiai ir tikèjimai. Silver Spring, Md.

Beresnevičius, G. 1990. Dausos. Vilnius.

Dundulienè, P. 1975. Mènulis lietuvių tikèjimuose. Kraštotyra. Vilnius, 256-268.

Dundulienè, P. 1988. Lietuviu kosmologija. Vilnius.

Greimas, A.J. 1990. Tautos atminties beieškant. Apie dievus ir žmones. Vilnius-Chicago.

Gusev, M. 1865. Drevnii litovskii kalendar'. Izvestija imperatorskogo arkheologicheskogo obshchestva. 5. St. Petersburg, pp. 335-354. 
Klētnieks, J. 1986. Nak kometa. Rīgā.

Lebedys, J. 1976. Lietuviu kalba XVII-XVIIIa. viešajame gyvenime. Vilnius.

Slaviūnas, Z. 1958. Sutartinès. 1. Vilnius.

Straubergs, K. 1944. Latviešu tautas paražas. Rīgā.

Šliavas, J. 1993. Žiemgalos tyrinèjimai. 1. Vilnius.

Vaiškūnas, J. 1991. Apie žvaigždžiu simbolika baltu pasaulēžiūroje. Liaudies kultūra, No. 2, pp. 35-37.

Vaiškūnas, J. 1995. Žinios apie dangaus šviesulius. Lietuvninku kraštas. Kaunas, pp. 694-708.

Vaiškūnas, J. \& Lovčikas S. 1999. Lithuanian Folk Knowledge of the Moon. Ancient times, modern methods. Ed. F.Stanescu. Sibiu, pp. 129-139.

Vaiškūnas, J. 2001. Birth and celestial bodies in Lithuanian and Latvian tradition. Astronomy, Cosmology and Landscape. Ed. C. Ruggles, F. Prendergast, T. Ray. Dublin, pp. 158-166.

Vaiškūnas, J. 2002. Žinios apie dangaus šviesulius Pelesos bei Ramaškonių apylinkèse. Lydos krašto lietuviai. 1. Kaunas, pp. 373-386.

Vaiškūnas, J. 2005. Žmogaus ir dangaus šviesulių santykis lietuvių tradicinèje kultūroje. Žmogaus samprata tradicinejje kultūroje. Konferencijos medžiaga, Vilnius, pp. 9-20.

Vaiškūnas, J. 2006. Observation of celestial bodies and timing practice in Lithuanian folk culture. Time and astronomy in past cultures. A. Sołtysiak (Ed.), Warszawa - Torun.

Vishinskii, P. 1935. Antopologicheskaja charakteristika Zhmudinov. Mūsu tautosaka 10, Kaunas, pp. 124-177. 